$\begin{gathered}\text { ADVANCE RESEARCH JOURNAL OF SOCIAL SCIENCE } \\ \text { ResEARCH } \\ \text { ARTICLE }\end{gathered}$
$\begin{gathered}\text { Volume 10 | Issue 2 | December, 2019 | 43-46 } \\ \text { ISSN-0976-5611 }\end{gathered}$
$\begin{gathered}\text { DOI: 10.15740/HAS/ARJSS/10.2/43-46 } \\ \text { Visit us : www.researchjournal.co.in }\end{gathered}$

\title{
Social and emotional well-being of rural mothers of Jorhat district
}

Krishna Baruah*, Jinamoni Saikia and Bondipa Dutta

Department of Human Development and Family Studies, College of Community Science, Assam Agricultural University, Jorhat (Assam) India

(Email : kiki_barua@yahoo.co.in)

\section{ARTICLE INFO :}

$\begin{array}{lll}\text { Received } & : & 27.06 .2019 \\ \text { Revised } & : & 02.11 .2019 \\ \text { Accepted } & : & 19.11 .2019\end{array}$

KEY WORDS :

Well-being, Rural mothers

HOW TO CITE THIS ARTICLE :

Baruah, Krishna, Saikia, Jinamoni and Dutta, Bondipa (2019). Social and emotional well-being of rural mothers of Jorhat district. Adv. Res. J. Soc. Sci., 10 (2): 43-46, DOI: 10.15740/HAS/ARJSS/ 10.2/43-46. Copyright@2019 : Hind Agri -Horticultural Society

*Author for correspondence

\begin{abstract}
The present study social and emotional well-being of rural mothers of Jorhat district was carried out in Jorhat district of Assam with an objective to assess the social and emotional well-being of the respondents and to find out the correlation between social and emotional well-being if any. Eleven villages were selected purposively from Jorhat district of Assam for the study. The study was conducted among 325 young rural mothers having children below 6 years of age. The findings revealed that 53.23 per cent respondents possessed good level of emotional health while in case of social health 48 per cent of respondents possessed the same.
\end{abstract}

